\title{
Optimalisasi Pemakaian Waste Material pada Beton terhadap Kondisi Normal Beton Perbandingan 1 PC:2 PS:3 KR
}

\author{
Agung Kristiawan'), Slamet Budiraharjo ${ }^{2)}$, Putri Anggi Permata Suwandi ${ }^{3)}$ \\ 1) Fakultas Teknik, Program Studi Teknik Sipil, Universitas PGRI, Semarang, Jl. Sidodadi Timur No. 24, \\ Karangtempel, Kec. Semarang Timur, Semarang; Telp. 024-8316377. Email: \\ kristiawan70ats@gmail.com \\ 2, 3) Fakultas Teknik, Program Studi Teknik Sipil, Universitas PGRI, Semarang, Jl. Sidodadi Timur No. \\ 24, Karangtempel, Kec. Semarang Timur, Semarang; Telp. 024-8316377.
}

\begin{abstract}
Abstrak
Material merupakan salah satu komponen penting dalam pelaksanaan suatu proyek konstruksi dan pemakaiannya harus dikontrol dengan baik sehingga tidak banyak sisa-sisa material yang terbuang dan menumpuk. Untuk minimalisasi sisa material akan menguntungkan pihak kontraktor dan bisa mengurangi dampak lingkungan. Sisa material konstruksi banyak sekali jenisnya seperti sisa material bata, pasir, split, begesting, dll. Pada pekerjaan plesteran membutuhkan pasir yang sudah diayak sesuai saringan yang dibutuhkan dan akan didapatkan sisa material ayakan pasir yang berbentuk kerikil. Sisa material kerikil dari ayakan pasir apabila tidak digunakan akan menumpuk dan dapat mengganggu pada penempatan material lain apabila lahannya tidak cukup luas. Sisa kerikil dari ayakan pasir tersebut dapat dipakai sebagai agregat kasar pada campuran beton sehingga sisa material tersebut dapat dioptimalkan lagi. Tujuan penelitian ini adalah untuk mengkaji karakteristik beton dengan mengoptimalisasikan sisa material, dalam hal ini kerikil sisa ayakan pasir sebagai pengganti agregat kasar campuran beton perbandingan $1 \mathrm{PC}: 2 \mathrm{PS}: 3 \mathrm{KR}$ dengan variasi pengaruh material sisa ayakan pasir terhadap agregat normal beton sebesar 10\%, 15\%, 20\%, 25\%, 30\%. Dari hasil uji laboratorium, karakteristik umum kuat tekan beton perbandingan 1 PC : 2 PS : 3 KR dengan agregat kasar memakai kerikil sisa ayakan pasir menunjukkan bahwa semakin besar persentase substitusi batu pecah dengan grosok maka kuat tekannya semakin turun. Karakteristik Kuat Tekan Kubus Beton Penambahan Portland Cement (PC) dengan Substitusi Grosok 5\% cukup dipengaruhi oleh besarnya penambahan PC, semakin besar persentase penambahan PC maka kuat tekannya semakin besar.
\end{abstract}

Kata kunci: agregat kasar, waste material, karakteristik beton.

\begin{abstract}
The material is one of the important components in a construction project and its use must be controlled properly so that not much remains of the material is wasted and piled up. The waste of construction materials that are not used will cause serious problems in the project. To minimize the remaining material will benefit the contractor also reduce the environmental impact. There are many types of construction materials such as brick, sand, split, formwork, etc. Plastering requires sand that has been sifted according to the required filter and the waste of the sand sieve material is gravel. The gravel waste material from the sand sieve is called 'grosok', will pile up and can interface with the placement of other materials if the land is not large enough. The 'grosok' can be used as coarse aggregate in the concrete mixture so that the waste material can be optimized. The purpose of this study was to examine the characteristics of concrete by optimizing the residual material, in this case, the gravel residue of sand sieve as a substitute for rough aggregate concrete mix 1 PC: 2 S: 3 GRV with a variation of the influence of sand filter material residuals in the normal aggregate of concrete by 10\%, 15\%, 20\%, 25\%, 30\%. From the results of laboratory tests, the general characteristics of concrete compressive strength of 1 PC: 2 S: 3 GRV with coarse aggregates using gravel residue sand sieve shows that the greater the percentage of crushed stone substitution with grosok, the compressive strength decreases. Compressive Strength Characteristics of Concrete Cubes The addition of Portland Cement (PC) with a 5\% Grosok substitution is quite influenced by the amount of the PC addition, the greater the percentage of the addition of a $P C$, the greater the compressive strength.
\end{abstract}

Keywords: rough aggregate, waste material, concrete characteristics.

\section{PENDAHULUAN}

Material pada proyek konstruksi merupakan komponen yang sangat penting dalam menentukan besarnya biaya pada pekerjaan konstruksi. Pemakaian material memegang peranan yang sangat penting dalam keberhasilan suatu proyek khususnya pada komponen biaya. Pada suatu proyek konstruksi seperti pembangunan gedung atau rumah tinggal tentunya membutuhkan berbagai jenis bahan material yang digunakan dan sering pada 
pelaksanannya terdapat banyak sisa-sisa material (waste meterial) yang tidak terpakai atau tersisa. Pemakaian material harus dikontrol dengan baik sehingga tidak banyak sisa-sisa material yang terbuang dan menumpuk. Sisa material konstruksi yang tidak dipakai akan menjadikan masalah yang serius dilapangan. Minimalisasi sisa material akan menguntungkan pihak kontraktor dan bisa mengurangi dampak lingkungan.

Berangkat dari pemikiran bahwa sisa material kerikil dari bekas ayakan pasir tersebut dapat digunakan sebagai bahan pengganti agregat kasar pada beton. Untuk menghasilkan beton yang baik, agregat halus maupun agregat kasar harus memiliki gradasi atau komposisi ukuran yang proporsional (Hidayat, 2009). Penelitian ini bertujuan untuk mengkaji karakteristik beton dengan mengoptimalisasikan sisa material, dengan mencari karakteristik umum kuat tekan beton perbandingan 1 PC : 2 PS : 3 KR dengan agregat kasar memakai kerikil sisa ayakan pasir pada variasi $10 \%, 15 \%, 20 \%, 25 \%$, $30 \%$ terhadap agregat kasar normal beton dan mencari Karakteristik Kuat Tekan Kubus Beton Penambahan Portland Cement (PC) dengan Substitusi Grosok 5\%. Semen adalah suatu jenis bahan yang memiliki sifat adhesif dan kohesif yang memungkinkan melekatnya fragmenfragmen mineral menjadi suatu massa yang padat (Murdock and Brook, 1993).

\section{METODE}

\section{Metode penelitian}

Metode Pelaksanaan penelitian diperlukan bahan, seperti semen portland, agregat halus dipakai pasir muntilan dan agregat kasar pada komposisi 1Pc : 2Ps : $3 \mathrm{Kr}$ untuk komposisi beton normal serta pemakaian waste material dalam hal ini memakai kerikil sisa ayakan pasir sebagai pengganti agregat kasar dengan beberapa variasi yaitu $10 \%, 15 \%, 20 \%, 25 \%$, $30 \%$ terhadap bagian agregat kasar pada beton normal. Antoni dan Nugraha, (2007), mengungkapkan bahwa pada beton yang baik, setiap butir agregat seluruhnya terbungkus dengan mortar. Untuk peralatan, seperti saringan/ayakan, timbangan dengan ketelitian 1 gram, gelas ukur, cawan, pengaduk, cetakan benda uji silinder beton, mesin uji tekan dengan menggunakan mesin uji tekan analog dan alat pendukung lainnya, seperti sendok aduk, alat penumbuk beton, dan ember.
Proses penelitian ini dibagi 6 (enam) tahapan yaitu tahap persiapan, tahap perhitungan, tahap pencampuran dan pengadukan, tahap pencetakan benda uji, tahap perawatan dan tahap pengujian.

a. Tahap persiapan, yaitu mencari data tentang agregat halus meliputi data analisis ayak dengan saringan $3 / 8$ ".

b. Tahap perhitungan, yaitu menentukan faktor air semen untuk tiap proporsi campuran pada beton normal perbandingan $1 \mathrm{Pc}: 2 \mathrm{Ps}$ : $3 \mathrm{Kr}$, serta menentukan takaran variasi limbah kerikil sisa ayakan pasir $10 \%, 15 \%$, $20 \%, 25 \%, 30 \%$ terhadap bagian agregat kasar beton normal.

c. Tahap pencampuran dan pengadukan, yaitu bahan yang sudah ditakar sesuai dengan perbandingan yang telah ditentukan, kemudian dimasukkan ke dalam media pengaduk secara berurutan, mulai dari agregat kasar, agregat halus, diaduk sampai merata, tambahkan semen, diaduk sampai merata, lalu tambahkan air, diaduk hingga merata. Apabila adukan dilihat sudah merata dan homogen kemudian dapat dituang cetakan silinder beton.

d. Tahap pencetakan benda uji, yaitu adukan dicetak dalam cetakan silinder beton sambil digetarkan dengan palu karet dan dijojok dengan besi jojokan sampai penuh dan diratakan.

e. Tahap perawatan benda uji, yaitu selesai pencetakan benda uji kemudian ditempatkan pada lingkungan yang lembab selama 24 jam/1hari. Setelah satu hari, cetakan dapat dibuka. Pengujian dilakukan pada umur 14 hari. Sebelum diuji dilakukan penimbangan terlebih dahulu untuk menghitung berat jenisnya.

f. Tahap pengujian, yaitu pengujian kuat tekan beton dilakukan pada umur 14 hari dengan menggunakan Mesin Kuat Tekan analog untuk mengetahui kuat tekan betonnya.

g. Tahap Analisis data, untuk mencari komposisi optimal dari seluruh campuran beton dengan pemakaian waste material kerikil sisa ayakan pasir dan variasi penambahan semen yang optimum untuk didapatkan kuat tekan yang seimbang dengan beton normal perbandingan $1 \mathrm{Pc}$ : $2 \mathrm{Ps}: 3 \mathrm{Kr}$. 
Kesimpulan, mengambil kesimpulan berdasarkan hasil analisis sebelumnya.

Sampel yang diuji untuk masing-masing campuran sebanyak 3 benda uji dengan ketentuan umum sebagai berikut:

$\mathrm{A}=$ Luas penampang benda uji

$$
\text { : } \quad 0,25^{*}(22 / 7) * \emptyset^{2} \text { (Silinder) }
$$$$
\text { : } \quad \text { P*L (Kubus) }
$$

tabel perbandingan kekuatan tekan beton

$\mathrm{n} \quad=$ pada berbagai umur (PC biasa)

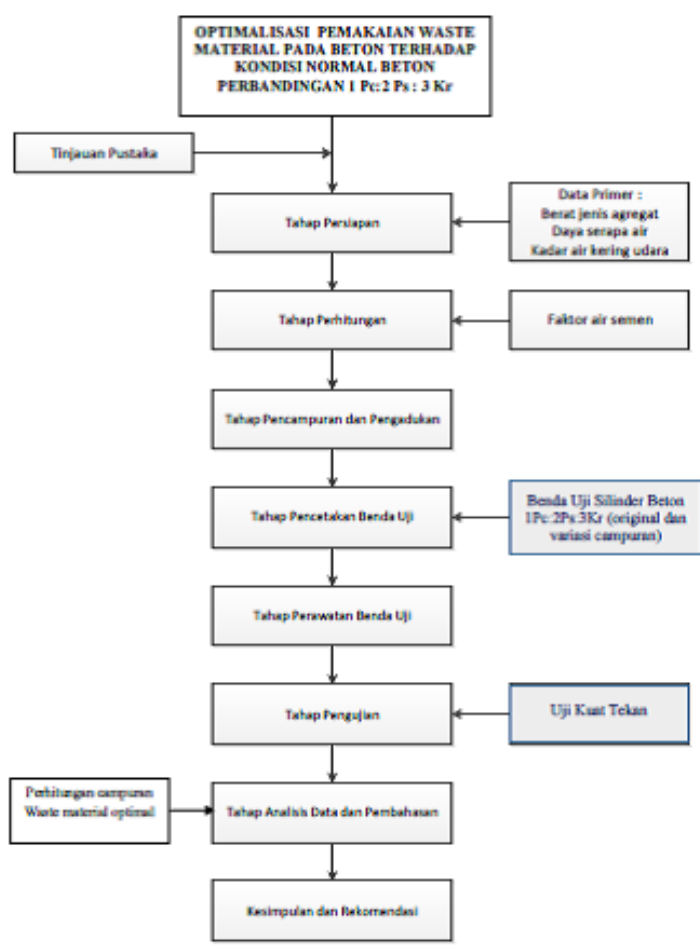

Gambar 1. Diagram alir

\section{HASIL DAN PEMBAHASAN}

3.1 Hasil Perbandingan Karakteristik Kuat Tekan Beton 1:2:3 tanpa substitusi grosok dan dengan Substitusi Grosok 5\%-30\%

Dari rata-rata hasil uji kuat tekan beton 1:2:3 dengan substitusi grosok 5\%-30\% di laboratorium, didapatkan hasil sebagai berikut:

Dari hasil Tabel 1 dibuat grafik untuk lebih memahami karakteristik dan perilaku campuran beton dengan substitusi grosok seperti pada Gambar 2.

Dari rata-rata kuat tekan beton yang disubstitusi dengan grosok, diilustrasikan pada gambar 4-8 tampak bahwa besarnya substitusi grosok cukup berpengaruh pada karakteristik kuat tekan beton. Pada gambar 4-8 tampak bahwa semakin besar persentase substitusi batu pecah dengan grosok maka kuat tekannya semakin turun. Turunnya kuat tekan beton dengan substitusi grosok besar kemungkinan akibat karakkenstitk 108okgk itu sendiri. Grosok memiliki permukaan yang bulat dan cenderung halus sehingga perlekatan antara grosok sebagai agregat pada beton menjadi berkurang sehingga semakin banyak substitusi campuran grosok menyebabkan turunnya karakteristik kuat tekan beton.

Tabel 1. Kuat Tekan Beton 1:2:3 Substitusi Grosok 5\%-30\%

\begin{tabular}{|c|c|c|}
\hline No. & Kode Benda Uji & $\begin{array}{c}\text { Kuat } \\
\text { Tekan } \\
\text { Beton } \\
\text { Rata-rata } \\
\text { (kg/cm2) }\end{array}$ \\
\hline [A] & [B] & $\begin{array}{c}{[\mathbf{K}]:} \\
{[\mathbf{J}] / \mathbf{0 , 8 3}}\end{array}$ \\
\hline 1 & Beton 1:2:3 & 117,48 \\
\hline 2 & Beton substitusi grosok 5\% & 91,53 \\
\hline 3 & Beton substitusi grosok $10 \%$ & 83,88 \\
\hline 4 & Beton substitusi grosok $15 \%$ & 71,27 \\
\hline 5 & Beton substitusi grosok $20 \%$ & 60,20 \\
\hline 6 & Beton substitusi grosok $25 \%$ & 41,96 \\
\hline 7 & Beton substitusi grosok $30 \%$ & 35,04 \\
\hline
\end{tabular}

\section{Kuat Tekan Beton Rata-rata} $(\mathrm{kg} / \mathrm{cm} 2)$

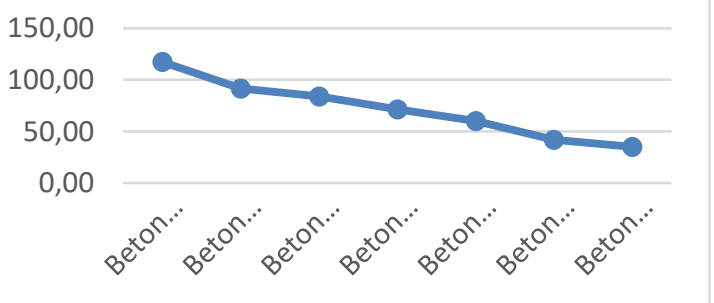

Gambar 2. Karakteristik Perbandingan Kuat

Tekan Beton 1:2:3 tanpa substitusi grosok dan dengan Substitusi Grosok 5\%-30\%

\subsection{Kuat Tekan Beton dengan Substitusi Grosok 5\% dan penambahan Portland Cement (PC)}

Dengan adanya substitusi batu pecah dengan grosok, ternyata menurunkan kuat tekan beton. Oleh karena itu diuji coba campuran beton dengan substitusi grosok yang diberi 
penambahan PC untuk memperbaiki kuat tekan beton. Uji coba laboratorium dilakukan pada Substitusi Grosok 5\% dan penambahan Portland Cement (PC) dengan campuran 1,25:2:3 ; 1,5:2:3 dan 2:2:3.

Dari rata-rata hasil uji kuat tekan beton penambahan PC dengan substitusi grosok 5\% di laboratorium, didapatkan hasil sebagai berikut:

Tabel 2. Kuat Tekan Beton dengan Penambahan Portland Cement substitusi grosok $5 \%$

\begin{tabular}{ccc}
\hline No. & Kode Benda Uji & $\begin{array}{c}\text { Kuat Tekan Kubus } \\
\text { Beton penambahan } \\
\text { PC substitusi grosok } \\
\mathbf{5 \%}(\mathbf{k g / c m})\end{array}$ \\
\hline$[\mathbf{A}]$ & {$[\mathbf{B}]$} & {$[\mathbf{K}]:[\mathbf{J}] / \mathbf{0 , 8 3}$} \\
\hline 1 & Beton $1,25: 2: 3$ & 150,09 \\
\hline 2 & Beton $1,5: 2: 3$ & 173,79 \\
\hline 3 & Beton $2: 2: 3$ & 196,17 \\
\hline
\end{tabular}

Dari hasil tabel diatas dibuat grafik untuk lebih memahami karakteristik dan perilaku campuran beton dengan substitusi grosok seperti pada gambar berikut ini:

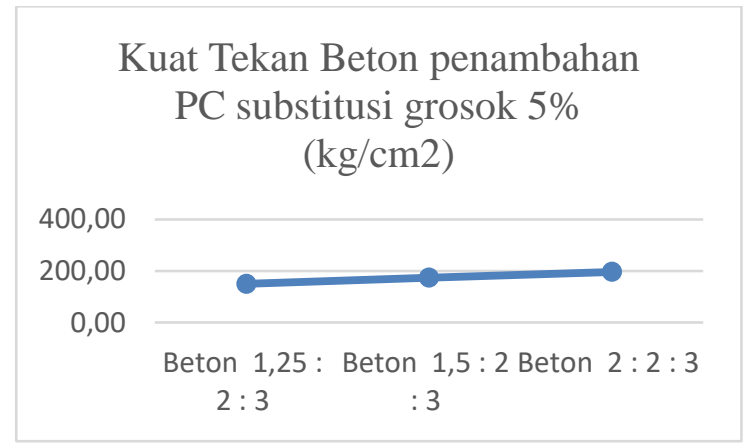

Gambar 3. Karakteristik Kuat Tekan Beton penambahan PC substitusi grosok 5\%

Dari rata-rata kuat tekan beton yang disubstitusi dengan grosok dan diberi penambahan PC, diilustrasikan pada gambar 4-12 tampak bahwa besarnya penambahan PC cukup berpengaruh pada karakteristik kuat tekan beton yang disubstitusi grosok 5\%. Pada gambar 4-12 tampak bahwa semakin besar persentase penambahan PC maka kuat tekannya semakin besar.

\section{SIMPULAN}

a. Kesimpulan Dari hasil uji laboratorium, karakteristik umum kuat tekan beton perbandingan $1 \mathrm{PC}: 2 \mathrm{PS}: 3 \mathrm{KR}$ dengan agregat kasar memakai kerikil sisa ayakan pasir pada variasi $5 \%, 10 \%, 15 \%, 20 \%$, $25 \%, 30 \%$ terhadap agregat kasar normal beton, substitusi grosok cukup berpengaruh pada karakteristik kuat tekan beton. Pada gambar 4-8 tampak bahwa semakin besar persentase substitusi batu pecah dengan grosok maka kuat tekannya semakin turun. Turunnya kuat tekan beton dengan substitusi grosok besar kemungkinan akibat karakteristik grosok itu sendiri. Grosok memiliki permukaan yang bulat dan cenderung halus sehingga perlekatan antara grosok sebagai agregat dengan beton menjadi berkurang sehingga semakin banyak substitusi campuran grosok menyebabkan turunnya kuat tekan beton.

b. Karakteristik Kuat Tekan Beton Penambahan Portland Cement (PC) dengan Substitusi Grosok 5\% cukup dipengaruhi oleh besarnya penambahan PC. Pada gambar 4-12 tampak bahwa semakin besar persentase penambahan PC maka kuat tekannya semakin besar.

\section{DAFTAR PUSTAKA}

Antoni, Nugraha, P., 2007. Teknologi Beton. Penerbit C.V Andi Offset. Yogyakarta, Indonesia.

Hidayat, Syarif, 2009, Semen Jenis dan Aplikasinya, PT. Pustaka Kawan. Jakarta, Indonesia.

Mulyono, T. 2005. Teknologi Beton, Penerbit Andi. Yogyakarta, Indonesia.

Murdock, L.J., Brook, K.M. dan Hendarko, S. (1993). Bahan dan Praktek Beton. Erlangga. Jakarta, Indonesia.

Nawy,E.G., 1990,"Beton Bertulang Suatu Pendekatan Dasar". Eresco. Bandung, Indonesia.

Segel, K. P., Kusuma, Gideon K., 1991, Pedoman Pengerjaan Beton, SK SNI T- 15 -1991 - 03) Seri Beton 2. Erlangga. Jakarta, Indonesia. 